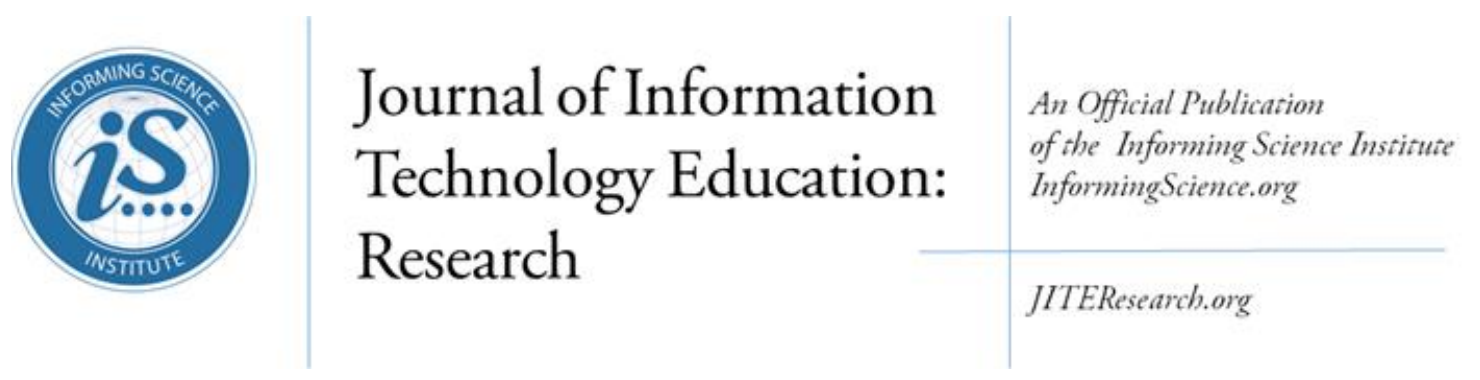

Volume 18, 2019

\title{
VEX ROBOTICS COMPETITIONS: GENDER DIFFERENCES IN STUDENT ATTITUDES AND EXPERIENCES
}

\begin{tabular}{lll}
\hline Amanda Sullivan* & $\begin{array}{l}\text { The DevTech Research Group at } \\
\text { Tufts University, Medford, MA, USA }\end{array}$ & Amanda.Sullivan@tufts.edu \\
Marina Umaschi Bers & $\begin{array}{l}\text { The DevTech Research Group at } \\
\text { Tufts University, Medford, MA, USA }\end{array}$ & Marina.Bers@tufts.edu \\
* Corresponding author &
\end{tabular}

ABSTRACT

Aim/Purpose Educational robotics competitions are a popular way to increase students' interest in science and engineering during their K-12 years. However, female students are typically underrepresented in these competitions. The goal of this study is to determine differences in the experiences of male and female robotics competition students in order to better support female students and increase their representation in competition leagues.

Background VEX Robotics Competitions are one of the fastest-growing educational robotics competitions available to middle school and high school students around the world. Despite growing numbers of participants, VEX programs have a noticeable lack of female participants. In order to create a more diverse and representative program, it is important to investigate why fewer female students participate in the competitions and what can be done to better support female students.

Methodology Qualitative and quantitative data were collected from VEX mentors and students through online surveys. A total sample of $N=675$ VEX mentors and students participated ( $n=47$ students and $n=628$ mentors). The surveys asked scaled, multiple choice, and free response questions. Through these surveys, the following research questions are answered: 1) What (if any) are the differences between male and female student experiences with VEX? 2) What (if any) are the differences in male and female students' confidence in their technical ability? and 3) What (if any) are the differences in male and female students' performance on VEX related robotics team tasks?

Accepting Editor Krassie Petrova | Received: October 11, 2018| Revised: December 22, 2018, January 11, 2019 | Accepted: January 23, 2019.

Cite as: Sullivan, A., \& Bers, M. U. (2019). Vex robotics competitions: Gender differences in student attitudes and experiences. Journal of Information Technology Education: Research, 18, 97-112. https://doi.org/10.28945/4193

(CC BY-NC 4.0) This article is licensed to you under a Creative Commons Attribution-NonCommercial 4.0 International License. When you copy and redistribute this paper in full or in part, you need to provide proper attribution to it to ensure that others can later locate this work (and to ensure that others do not accuse you of plagiarism). You may (and we encourage you to) adapt, remix, transform, and build upon the material for any non-commercial purposes. This license does not permit you to use this material for commercial purposes. 
Gender Differences in VEX Robotics Competition Student Experiences

Contribution

Findings

Recommendations for Practitioners

Recommendations for Researchers

Impact on Society

Future Research

Keywords
This study contributes to the growing body of work on engaging female students, and other underrepresented students, in STEM fields such as programming, engineering, and robotics.

Results demonstrate the male students outnumber female students and male mentors also outnumber female mentors in this sample. Male students are significantly more confident in their general technical ability and their ability to put things together $(p<.05)$ and students of both genders generally wished to have more female students on their teams. Results also indicate that mentors generally perceive their female students as requiring more help and that they are less engaged with construction tasks as compared to male students.

VEX mentors should focus on enhancing female students' confidence with the construction and building aspects of robotics and ensuring they get the same experience with these tasks as male students. They should consider providing supplemental hands-on training sessions, within or outside of regular team sessions, for students who wish to build confidence and experience in these areas.

Researchers should continue to explore the experiences of female students in robotics competitions, including differences based on grade level, mentor gender, and more. Researchers should additionally look at female students who are not a part of robotics teams (or who have left a robotics team) to understand why these teams do not appeal to them.

Women are still underrepresented in engineering and computer science professions. In order to bridge this gap, it is critical to find effective ways to reach girls in their K-12 years to build their confidence and interest in these fields before they reach college. This study points out critical areas where robotics competition teams should focus on building female students' confidence.

The findings in this paper present research from year 1 of a multi-year longitudinal study. Future research will continue to track the mentors and students in this study in order to gain information on retention and change over time.

gender, robotics, programming, competitions, STEM

\section{INTRODUCTION}

Across the United States and globally, educational robotics competitions have been rapidly growing in popularity. One reason for the rise in robotics competitions is they are thought to promote an interest in Science, Technology, Engineering, and Mathematics (STEM) domains and may increase students' likelihood of considering STEM professions later in life (Hendricks, Alemdar, \& Olgletree, 2012; Petre \& Price 2004). Preparing future STEM professionals has become a growing concern for educators and researchers. According to the Bureau of Labor Statistics, it is estimated that computer related fields will have over 1 million job openings from 2014 to 2024 (Fayer, Lacey, \& Watson, 2017). In less than ten years from now, it is estimated that the United States will need 1.7 million more engineers and other technical professionals to fill these roles (Corbett \& Hill, 2015). Therefore, it is essential that educators find new ways to pique the interest future engineers to meet this growing need.

Despite the continued growth of the STEM workforce, the representation of women in many STEM fields, particularly the technology-focused areas like engineering and computer science, is still drastically less than the representation of men (National Science Foundation, 2017). Only 15\% of engineers are women and only approximately a quarter of math and computer scientists combined 
are women (National Science Board, 2014). From an ethical standpoint, it is important that the opinions and experiences of women are heard when creating the technical innovations that continue to impact our everyday lives as these fields continue to grow. In order to address the growing needs of the STEM workforce, and increase the diversity of representation in STEM fields, there has been a recent focus on starting early to prepare future engineers through in-school and out-of-school technical activities, such as robotics competition leagues, while they are still in their K-12 schooling years.

One of the fastest-growing educational robotics competitions available to middle school and high school students around the world are the VEX Robotics Competitions. The most recent VEX Robotics World Championship, run by the Robotics Education and Competition (REC) Foundation in April of 2018, had a record-setting number of participants and became the "largest robot competition" in the world according to Guinness World Records (Stephenson, 2018). However, even with the growing number of participants in VEX competitions, female students are estimated to make up only 23\% of VEX participants (Girl Powered, 2018). This percentage is reflective of the lack of women in professional engineering and computing careers. Research shows that in order to increase the number of women in engineering and computing related careers, it is important to begin reaching female students long before they enter college (Corbett \& Hill, 2015; Markert, 1996; Metz, 2007; Sullivan \& Bers, 2016). The present research examines the current state of female representation and experiences in VEX Robotics Competitions with the goal of determining strategies for engaging more female students to participate. The study presented in this paper provides pilot findings based on year 1 of a multi-phase research project tracking the experiences of students in VEX robotics programs over the course of three years. This study asks the following exploratory research questions:

1) What (if any) are the differences between male and female student experiences with VEX?

2) What (if any) are the differences in male and female students' confidence in their technical ability?

3) What (if any) are the differences in male and female students' performance on VEX related robotics team tasks?

Implications for providing supports for female students and ultimately increasing female participation in VEX and other robotic programs are discussed.

\section{LITERATURE REVIEW}

\section{GENDER DISPARITY IN TECHNOLOGY AND ENGINEERING}

In most technical STEM careers, men still greatly outnumber women. According to the National Science Foundation's recent workforce statistics, STEM professions including computer science, physics, and engineering remain predominantly male (National Science Foundation, 2017). Overall, women's representation in engineering and computer science fields is below 30\% (National Center for Science and Engineering Statistics, 2013). Additionally, in the past 10 years, the total number of female undergraduates earning a bachelor's degree in computer science has gone down (National Science Foundation, 2017).

Long before women enter college or the career world, they are exposed to stereotypes that influence their interest in technical domains. Beginning in early childhood and throughout their middle and high school years, girls and young women are exposed to stereotypes that inform ideas about their identity, abilities, and interest in STEM fields. (Kuhn, Nash, \& Brucken, 1978; McKown \& Weinstein, 2003; Metz, 2007; Signorella, Bigler, \& Liben, 1993; Steele, 1997). During adolescence, the gender gap with regard to standardized STEM test scores and participation in STEM courses becomes more defined (Corbett \& Hill, 2015; Spielhagen 2008). For example, by high school, male students are 
more likely than female students to take engineering and computing focused standardized exams (Corbett \& Hill, 2015). Female high school students are also less likely than male students to enroll in Advanced Placement Computer Science classes or to express a desire to study computer science related subjects in college (Doerschuk et al. 2007; Zweben \& Bizrot, 2015). This gap during high school is a major concern to researchers, as the courses and exams students take in high school can directly impact what students are prepared to study in college and go on to pursue professionally.

In order to increase the number of females in technical STEM careers, educators and researchers have begun focusing on increasing girls' interest in STEM through initiatives that take place during their K-12 years. Past research suggests that exposing young children to STEM curriculum early on may prevent them from acting on gender-based stereotypes about STEM careers when they get older (Metz, 2007; Steele, 1997) and may also limit the number of roadblocks they have pursuing these fields down the road (Madill et al., 2007; Markert, 1996). Robotics can be a hands-on way for female students to gain skills in building, coding, engineering, design, and more beginning in early elementary school (Sullivan \& Bers, 2016; Sullivan \& Bers, 2018). For example, research with the KIBO robot has shown that beginning in early elementary school, boys are already significantly more interested in engineering than girls, and that completing a hands-on KIBO robotics curriculum increased girls' interest in engineering so that this gender difference was eliminated (Sullivan, 2016; Sullivan \& Bers, 2018).

With the abundance of educational robotics competitions across the United States, this is an area that could potentially reach many female students. The following sections describe educational robotics competitions and female experience and representation in these leagues.

\section{ROBOTICS COMPETITIONS}

Robotics competitions have been popular at the university level for quite some time. At MIT, a robotics design and building competition for mechanical engineering students, originally started by Professor Flowers in the 1970s, has flourished into an annual and much anticipated university tradition (Mallinson, 2015). As part of this event, teams of MIT students work for four weeks designing, constructing, and programming robots to compete. Their robots must be built to complete a specific task in the competition (Mallinson, 2015). Faculty, students, and staff gather to watch the finals of the competition. The gathering of an audience and a public culmination to the building and design work makes robotics competitions akin to public games and matches in competitive sports leagues.

Now, robotics competitions have also become a popular extracurricular activity for school-aged students in Kindergarten through high school. Some of the most popular competitions for K-12 students include the FIRST Robotics Competition, the World Robot Olympiad competition, and the VEX Robotics Competition. These competition leagues are thought to foster students' interest in math and science (Hendricks, Alemdar, \& Olgletree, 2012; Petre \& Price 2004). Beyond math and science, robotics has been shown to have a range of educational benefits, such as teaching foundational computational thinking skills, the design process, and engaging students creatively, as an expressive medium (Bers, 2018; Bers 2008). Like other extracurricular leagues and programs for kids, robotics competitions have become a popular way to engage children and adolescents in powerful learning experiences in an informal learning environment.

On the other hand, some researchers have found that competitive team environments may not be the best experience for children. For example, competitions focus on extrinsic motivation (i.e., winning, beating an opponent) and may therefore lower one's intrinsic motivation to complete the activity at hand (Fortier, Vallerand, Briere, \& Provencher, 1995). Additionally, some have found that children who have competitive trait anxiety may experience fear of failure and fear of evaluation on competitive sports teams (Passer, 1983). 


\section{GENDER ISSUES AND ROBOTICS COMPETITIONS}

While robotics competitions may encourage students to learn more about fields such as programming and engineering, research also demonstrates that gender gaps exist in these competitive environments and that this gap grows noticeably with the age of students and level of complexity of competitions (Witherspoon, Schunn, Higashi, \& Baehr, 2016). Looking back at the MIT robotics competitions described in the previous section, two Wellesley college professors noted that these competitions had fewer than $20 \%$ female participation, despite the fact that the student body was $40 \%$ female (Rusk, Berg, \& Resnick, 2005). They hypothesized that for a similar robotics event to work at Wellesley, an all-female college, a different approach was needed and they developed a course called "Robotic Design Studio." Similar to the MIT robot competition, the Robotic Design Studio was implemented as a month-long immersive experience that culminated in a gathering of students, faculty, and staff. But instead of culminating in competition, Wellesley students shared their artistic robotic creations in an exhibition of their inventions, much like a new installation at an art gallery (Rusk, Berg, \& Resnick, 2005). Other research with younger students has supported this idea that a different, non-competitive approach, may be needed to reach female roboticists. Sullivan and Bers (2018) found that implementing a KIBO robotics curriculum that focused on collaboration and helping (students created robots to help improve their school community) was an effective way to increase early elementary girls' interest in engineering.

For these reasons, it may not be surprising that female students are generally underrepresented on competitive K-12 robotics teams. Prior evaluations of the FIRST LEGO League, for example, has shown that males outnumber females 5 to 2 (Melchior, Cutter, \& Cohen, 2004). Additionally, in a study of students from FIRST and VEX competitions, Witherspoon et al. (2016) found that female students were more likely than male students to participate in elementary school competitions and other and entry-level competitions, but that this changes by the time female students reach competitions at the high school level, when male students outnumber female students. This shift is mirrored by the representation of female mentors and entry-level versus advanced competitions. In a 2012 study that surveyed 345 mentors in VEX Robotics programs, the researchers found that middle school robotics teams had fairly even representation of male and female mentors, but amongst the more advanced high school teams, fewer than $27 \%$ of mentors were female (Hendricks, Alemdar, \& Olgletree, 2012).

It is also possible that the competitive nature of these robotics programs is simply not as appealing to adolescent females as it is to adolescent males. Research has shown that even women with high levels of computer self-efficacy are drawn to cooperative learning styles (Salminen-Karlsson, 2009). Further research is necessary in order to determine what factors can keep girls engaged in robotics competitions through high school and whether these experiences actually lead them to pursue STEM majors in college and STEM careers later in life or not. This study begins to fill the gap in research by looking at the experiences of male and female students in the VEX robotics competitions in an effort to better support female students on VEX teams.

\section{VEX ROBOTICS COMPETITIONS}

The VEX Robotics Competition is a robotics competition that engages participants from elementary through university students in learning about engineering, coding, robotics, and more. VEX educational robotics was launched in 2005 in order to offer students and educators an affordable and accessible opportunity to get involved with hands-on robotics programs. Today, the VEX robotics program makes up one of the largest extracurricular robotics programs in the world. It has 18,000 teams across 40 countries ranging students from elementary through college. Teams in the United States make up approximately $80 \%$ of the program. Each team has an average of 6-9 students per and 1-2 mentors. 
Although the VEX program is extensive, there is a noticeable lack of females participating in this program. Only 23 percent of VEX participants are female (Girl Powered, 2018). This study examines the experiences of male and female students in VEX robotics competitions in order to determine why male students outnumber female students and what can be done to improve the robotics competition experience for all students, and especially female students. This is research is aligned with the new "Girl Powered" initiative launched by the REC Foundation and VEX Robotics which seeks to increase female participation in VEX Competitions (see: www.girlpowered.com). Ultimately, the long-term goal of this work is to increase female representation in extracurricular robotics and engineering programs, such as VEX robotics competitions, in order to provide girls and young women with equal preparation and opportunity to pursue STEM majors in college and the professional world.

\section{METHODS}

\section{OVERVIEW}

This study presents data collected from VEX students and mentors through online surveys. The findings presented here are exploratory findings from Year 1 of a three-year longitudinal study. The goal of this study is to get an initial sense of gender demographics, team dynamics, and gender differences in order to guide future waves of the research and to ultimately make recommendations of strategies to better support female students on VEX teams.

\section{SAMPLE}

This study's sample is made up of VEX mentors and VEX students. VEX mentors were recruited to participate in this study through email solicitation. A sample of $n=628$ mentors participated in the Mentor Survey. Of those 628 mentors, 566 responded regarding their gender. Mentors in this sample were: $n=330$ were male, $n=230$ were female, $n=2$ were another gender, and $n=4$ preferred not to say.

In order to reach VEX students, researchers collaborated with VEX mentors who either provided parent emails or forwarded a link to study materials directly to parents. Parents then completed consent forms for any students under the age of 18 before their child was able to complete the survey. An initial sample of 64 students submitted the VEX Student Survey online. When removing those who did not include proper parental consent information, there were 63 students. When removing those who did not answer any questions beyond the consent, a final student sample of $n=47$ students are included in analysis. These students ranged from 5th-12th grade. Students in this sample were: $n=31$ males, $n=14$ females, and $n=2$ left this question blank. No students identified as transgender or another gender. In addition to reporting their own gender, students were asked to share their mentor gender if that information was known to them. More than half $(60 \%)$ of students reported having a male mentor on their team.

\section{DATA COLLECTION}

Data was collected from mentors and students through short online surveys (a Mentor Survey and Student Survey, respectively) that included multiple choice, scaled questions, and free response questions relating to VEX activities. The Mentor Survey asked mentors questions about their perceptions of students, their overall experiences, and their mentoring practices. The Student Survey asked students questions about their general team experiences and questions relating to their interest and confidence in areas relevant to VEX activities. Additionally, students were asked questions related to their mentoring experience. 


\section{RESULTS}

Results are presented in the following section in response to the three research questions explored in this study:

1) What (if any) are the differences between male and female student experiences with VEX?

2) What (if any) are the differences in male and female students' confidence in their technical ability?

3) What (if any) are the differences in male and female students' performance on VEX related team tasks?

Quantitative results are presented as well as qualitative results in the form of common themes, words, or topics that emerged from coding the free-response survey questions. In order to provide examples of survey responses related to each theme that emerged, illustrative quotes are provided. Please note that these quotes are a small selection of examples to help convey each theme, not an exhaustive list.

\section{GENDER DIFFERENCES IN STUDENT EXPERIENCES WITH VEX}

According to the demographic data collected, male students outnumber female VEX students, with $65 \%$ of this sample being male (See Figure 1). This was aligned with data collected from the mentor survey in which numerous mentors commented that they had few female students on their teams and how they hoped to have more female students in future years. For example, one mentors said, "[] have limited experience in mentoring girls. Desperately hoping that changes soon.”

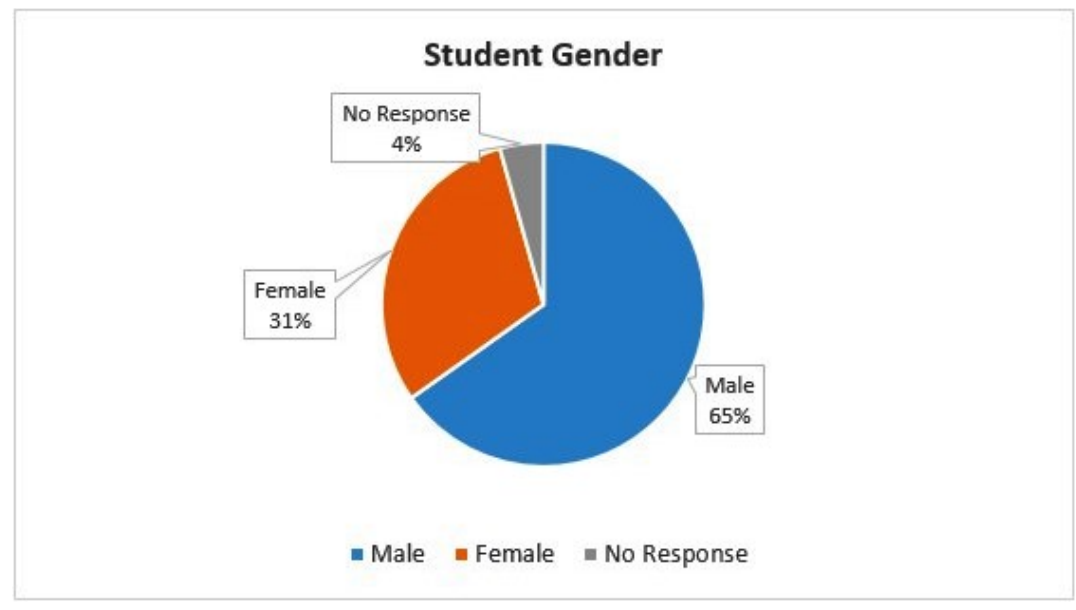

Figure 1. Gender demographics of students

Students generally agreed with this mentor sentiment, wishing that there were more female members on their teams. They were asked to rate how strongly they agreed with the following statements on a scale of $1-5(1=$ do not agree, $5=$ strongly agree): Statement 1 - I wish there were more girls on my team and Statement 2- I wish there were more boys on my team. Students showed a higher mean desire for there to be more girls on their team (See Figure 2). While both male and female students desired more female students on their teams, male students felt particularly strong in this respect ( male mean $=3.88$; female mean $=2.67$; all students combined $=3.53$ ).

Students were also asked questions about their mentoring experience to determine if there were any gender differences in students' satisfaction with their mentors. Overall, students were reportedly quite satisfied with their experiences with their mentors (See Figure 3). Students were asked how much they agreed with several statements about their mentors on a scale of 1-5 (1=do not agree, $5=$ strongly agree). Students generally strongly agreed that their mentor helps foster positive relation- 
ships amongst students (mean=4.44) and that their mentors give the right kind of help (mean=4.36). Students generally disagreed that their mentors should know more, help out more, or interfere less.

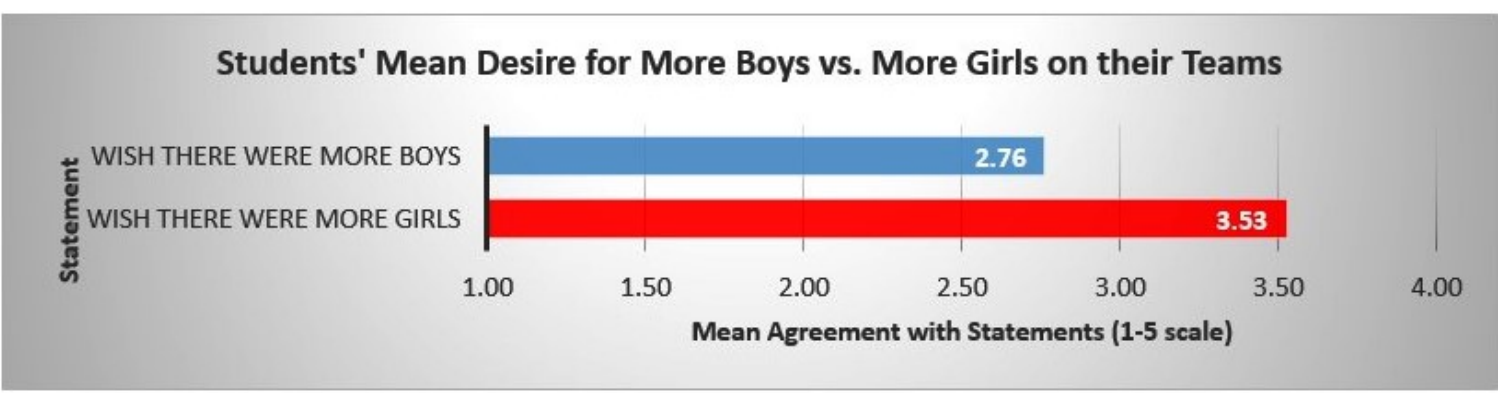

Figure 2. Students' Desire for More Boys or More Girls on their Teams

There were low levels of agreement that mentors help build the robots (mean=2.26) or program their robots (mean=2.58), indicating these are generally student directed activities. There were no statistically significant differences between male and female students and their satisfaction with their mentors on any of the items assessed ( $p>.05)$.

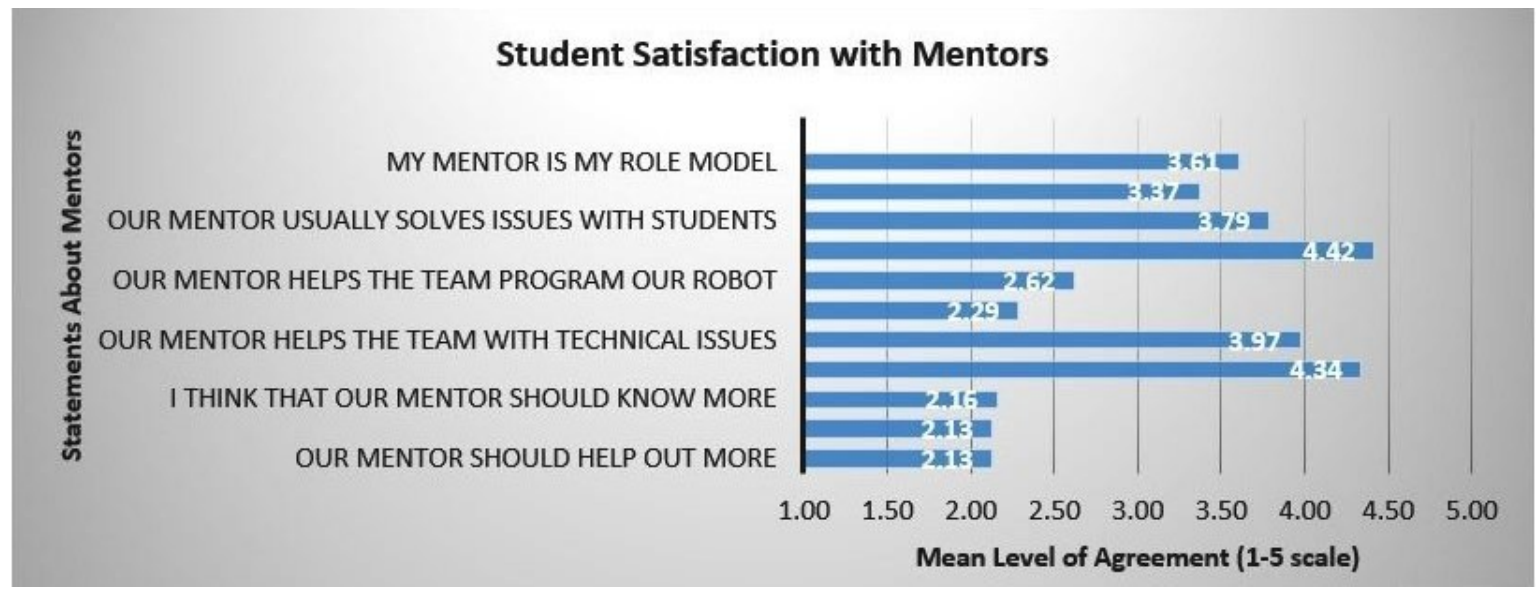

Figure 3. Students' Satisfaction with Mentoring Experience

Mentors were also asked to comment on gender dynamics and student experiences on their teams. When asked whether there were differences in the roles and activities of male and female students on their VEX teams, close to half of the mentors $(46.71 \%)$ stated that there was no difference while $43.21 \%$ said there was some difference between males and females on their team. 10.08\% said there were huge differences based on student gender. Mentors had a chance to further elaborate on this in free response form. After coding through these responses for common themes related to gender differences, results show that mentors generally felt male students gravitate more towards hands-on construction related tasks and that female students shy away from this. Furthermore, male students tend to take on more of a leadership role on the teams while female students tend to play more passive roles on the team (See Table 1 for examples).

\section{GENDER DIFFERENCES IN STUDENT CONFIDENCE}

The second research question asked if there were any gender differences in VEX student confidence. Results from free response questions on the Mentor Survey were coded for common themes related to student confidence. These themes are summarized with examples in Table 2 . The themes suggest that female students have less confidence in their technical ability and their ability with building and constructing tasks. 
Table 1. Gender Differences in Team Roles \& Dynamics: Illustrative Quotes from Mentors

\begin{tabular}{|c|c|}
\hline Theme & Illustrative Quotes \\
\hline Males take the lead & $\begin{array}{l}\text { "The females tend to stand back and let the males take the lead in building even if } \\
\text { the males don't know any more about the task." } \\
\text { "Both males and females are good at constructing, but the males are prone to take } \\
\text { over." } \\
\text { "The girls tend to sit back and take a more passive role when on a team of mixed } \\
\text { gender if not given a little push, and guys will exclude girls if not shown the value of } \\
\text { her as a teammate." }\end{array}$ \\
\hline $\begin{array}{l}\text { Females shy away from } \\
\text { building/construction }\end{array}$ & $\begin{array}{l}\text { "Most of the girls I have aren't as inclined to want to actually build something. They } \\
\text { have to be encouraged to use a wrench." } \\
\text { "Females at my school have had less experience at constructing so they feel insecure } \\
\text { or just do not know how to put things together to make what they want." }\end{array}$ \\
\hline
\end{tabular}

Students were also asked to rate their level of confidence on each of their abilities and skills related to VEX robotics tasks. Independent sample $T$-tests were used to calculate areas of statistically significant differences between male and female students' confidence in each of the areas (see Table 3). Based on these tests, there were two areas where males and females had significantly different levels of confidence: their general technical ability and their ability to put things together. In both of these cases, male students were significantly more confident than females. There were no other significant differences between male and female students.

Table 2. Mentor Perceptions of Gender \& Student Confidence

\begin{tabular}{|l|l|}
\hline \multicolumn{1}{|c|}{ Theme } & \multicolumn{1}{c|}{ Illustrative Quotes } \\
\hline Female students need time to build their confidence & $\begin{array}{l}\text { "The girls just need a confidence boost to allow them } \\
\text { time to do it themselves so they know they can." } \\
\text { "Boys are more likely to dive right in, girls are more } \\
\text { hesitant. As time goes on and they gain confidence } \\
{[\text { and] there is very little difference." }}\end{array}$ \\
\hline $\begin{array}{l}\text { Female students are worried about social repercus- } \\
\text { sions in areas where they lack confidence }\end{array}$ & $\begin{array}{l}\text { "My female students did not want to embarrass them- } \\
\text { selves. They were afraid they would be mocked. It was } \\
\text { not a lack of skill. It was having to deal with ridicule } \\
\text { from their male counterparts." }\end{array}$ \\
\hline
\end{tabular}

Table 3. Results of Independent Sample $T$-Tests for Male and Female Student Confidence

\begin{tabular}{|c|c|c|c|c|c|c|c|c|c|}
\hline \multicolumn{10}{|c|}{ Gender } \\
\hline & \multicolumn{3}{|c|}{ Male } & \multicolumn{3}{|c|}{ Female } & \multirow[b]{2}{*}{$t$} & \multirow[b]{2}{*}{$d f$} & \multirow[b]{2}{*}{$p$} \\
\hline & $M$ & $S D$ & $n$ & $M$ & $S D$ & $n$ & & & \\
\hline $\begin{array}{l}\text { Good at technical } \\
\text { things }\end{array}$ & 4.62 & .50 & 26 & 3.82 & .87 & 11 & -3.53 & 35 & $.001 *$ \\
\hline $\begin{array}{l}\text { Good at putting } \\
\text { things together }\end{array}$ & 4.69 & .55 & 26 & 4.00 & .45 & 11 & -3.69 & 35 & $.0008^{*}$ \\
\hline $\begin{array}{l}\text { Confident I can } \\
\text { design and build } \\
\text { stable robot }\end{array}$ & 4.30 & .93 & 26 & 4.00 & 1 & 11 & -.9 & 35 & .37 \\
\hline $\begin{array}{l}\text { Confident that I can } \\
\text { program the robot }\end{array}$ & 3.08 & 1.41 & 26 & 3.73 & 1.56 & 11 & 1.24 & 35 & .22 \\
\hline $\begin{array}{l}\text { Confident that I can } \\
\text { collaborate with } \\
\text { team members }\end{array}$ & 4.46 & .71 & 26 & 4.55 & .52 & 11 & .35 & 35 & .73 \\
\hline
\end{tabular}


Gender Differences in VEX Robotics Competition Student Experiences

\begin{tabular}{|c|c|c|c|c|c|c|c|c|c|}
\hline $\begin{array}{l}\text { Confident that I can } \\
\text { coach our drivers } \\
\text { through a match }\end{array}$ & 4.15 & 1.32 & 26 & 4.18 & 1.08 & 11 & .06 & 35 & .95 \\
\hline $\begin{array}{l}\text { Confident that I can } \\
\text { scout out good } \\
\text { teams to partner } \\
\text { with }\end{array}$ & 3.92 & 1.18 & 26 & 4.55 & .69 & 11 & 1.61 & 35 & .12 \\
\hline $\begin{array}{l}\text { Confident in my } \\
\text { writing skills }\end{array}$ & 3.62 & 1.33 & 26 & 3.91 & 1.04 & 11 & .65 & 35 & .52 \\
\hline $\begin{array}{l}\text { Confident in my } \\
\text { presentation skills }\end{array}$ & 4.23 & 1.07 & 26 & 4.18 & .87 & 11 & -.13 & 35 & .90 \\
\hline
\end{tabular}

*significant difference between males and females $\mathrm{p}<.05$

Finally, independent sample $T$-tests were also used to calculate areas of statistically significant differences between male and female students with relation to the areas they wish to improve (See Table 4). According to these tests, there were no statistically significant differences between male and female students in the areas they wish to improve ( $p>.05$ for all areas).

Table 4. Results of Independent Sample T-Tests for Male \& Female Students' Areas of Improvement

\begin{tabular}{|c|c|c|c|c|c|c|c|c|c|}
\hline \multicolumn{10}{|c|}{ Gender } \\
\hline & \multicolumn{3}{|c|}{ Male } & \multicolumn{3}{|c|}{ Female } & \multirow[b]{2}{*}{$t$} & \multirow[b]{2}{*}{$d f$} & \multirow[b]{2}{*}{$p$} \\
\hline & $M$ & $S D$ & $n$ & $M$ & $S D$ & $n$ & & & \\
\hline Technical things & 4 & 1.29 & 25 & 3.73 & 1.19 & 11 & -6 & 34 & .55 \\
\hline $\begin{array}{l}\text { Putting things to- } \\
\text { gether }\end{array}$ & 3.88 & 1.31 & 26 & 4.18 & .87 & 11 & .69 & 35 & .49 \\
\hline $\begin{array}{l}\text { Designing and } \\
\text { building a stable } \\
\text { robot }\end{array}$ & 4.12 & 1.34 & 26 & 4.27 & .65 & 11 & .37 & 35 & .71 \\
\hline $\begin{array}{l}\text { Programming the } \\
\text { robot }\end{array}$ & 4.38 & .98 & 26 & 4.36 & .92 & 11 & -.06 & 35 & .95 \\
\hline Collaboration & 4.23 & 1.28 & 26 & 4.55 & .69 & 11 & .83 & 35 & .41 \\
\hline Coach drivers & 3.92 & 1.44 & 26 & 4.18 & .75 & 11 & .56 & 35 & .60 \\
\hline $\begin{array}{l}\text { Scout teams to part- } \\
\text { ner with }\end{array}$ & 3.77 & 1.39 & 26 & 4.36 & .67 & 11 & 1.34 & 35 & .19 \\
\hline Writing & 3.62 & 1.24 & 26 & 4.36 & .67 & 11 & 1.88 & 35 & .07 \\
\hline Presenting & 3.85 & 1.16 & 26 & 4.55 & .69 & 11 & 1.86 & 35 & .07 \\
\hline
\end{tabular}

\section{GENDER DIFFERENCES IN PERFORMANCE ON TASKS}

The final research question looks at whether there were any differences in male and female students' performance on VEX related tasks. To answer this question, mentors were asked whether male or female students require more help on each task (see Figure 4). For the most part, mentors generally responded that there were no differences between male and female students on the help they require on different activities. The biggest differences were regarding collaboration (172 mentors said male students require more help collaborating while only 29 mentors said female students need more help collaborating) and constructing (122 mentors said female students require more help constructing, while only 47 mentors said males need more help constructing).

In the free response portions of the survey, the mentors also generally elaborated on female students' lack of experience with building and constructing (See Table 5). This was the main area where mentors felt that female students needed more support to build their skills. Many mentors further explained that this was because male students came into the program with a great deal more prior experience building compared to female students. 


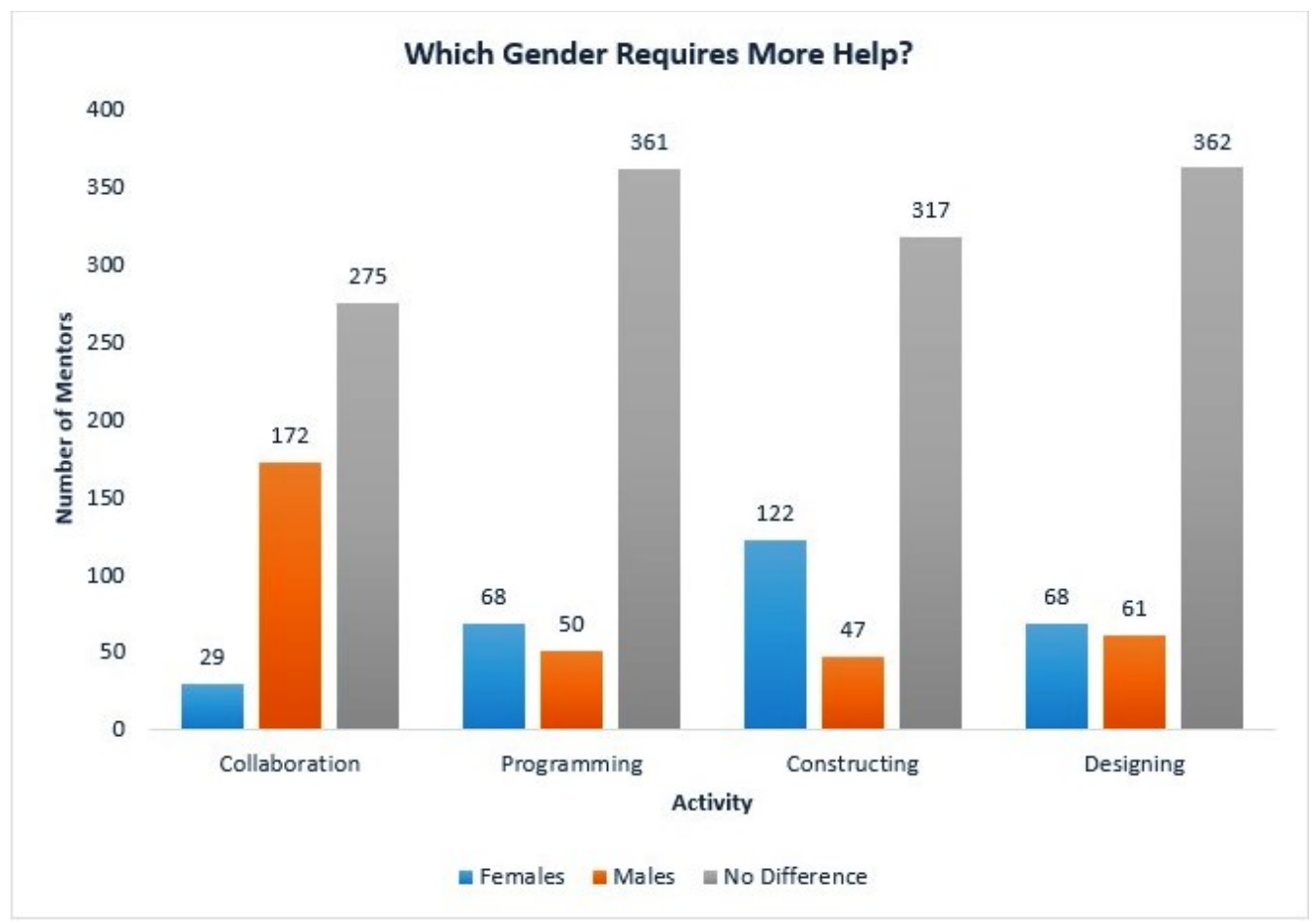

Figure 4. Gender Differences in Help Required to Complete Tasks

Table 5. Gender Differences in Building \& Construction Experience

\begin{tabular}{|l|l|}
\hline Theme & Illustrative Quotes \\
\hline $\begin{array}{l}\text { Male students enter with prior experi- } \\
\text { ence building that female students } \\
\text { don't have }\end{array}$ & $\begin{array}{l}\text { "Guys have had more building experience." } \\
\text { "Males seem to have more past experiences with construction (Lego's, } \\
\text { tools, etc.)" }\end{array}$ \\
\hline $\begin{array}{l}\text { Female students need explicit training } \\
\text { and support with construction tasks }\end{array}$ & $\begin{array}{l}\text { "Girls need to be instructed more in the beginning because they never } \\
\text { "Females at my school have had less experience at constructing so they } \\
\text { feel insecure or just do not know how to put things together to make } \\
\text { what they want." }\end{array}$ \\
\hline
\end{tabular}

\section{DISCUSSION}

Findings from this exploratory study suggest that all students, both male and female, have had an overall positive experience on their VEX robotics competition teams. On average, students were satisfied with their mentoring experience and felt that their mentors help foster positive relationships between team members. There were no gender differences in terms of mentor satisfaction, indicating that both male and female students are satisfied with their mentoring experience. Results, however, also confirmed the underrepresentation of female students as well as female mentors. It also identified two areas where female students are less confident than their male counterparts: putting things together and general technical ability. Finally, the results also indicated that female students are entering the VEX programs with less technical and building experience than male students. This is likely related to their issues with confidence and should be considered when developing strategies to support females on VEX teams. 


\section{UNDERREPRESENTATION OF FEMALE MENTORS AND STUDENTS}

This study provides preliminary evidence that female students are underrepresented on VEX robotics competition teams. Results indicate that male students make up $65 \%$ of the sample while female students make up just $31 \%$ of the sample ( $4 \%$ left this question blank). However, it is important to note that at $31 \%$, this percentage of female students is slightly higher than the $23 \%$ statistic posted online (see: https://www.girlpowered.com/why-girl-powered/). This may be due to the specific sample of students who replied to this survey. Future work will continue to expand on the sample size of students in order to make more representative claims about the VEX student population. Students in this sample also had fairly high mean desire for more female students on their teams. This indicates a need to recruit and retain more female students on VEX teams.

Students also provided their mentor's gender, if it was known to them. Here we again see that males outnumber females. In this sample, $60 \%$ of students reported that their mentors were male. Despite this, there were no significant differences between male and female students in their ratings of their mentoring experience or whether they see their mentor as a role model. However, it may still be worth considering that increasing the number of female mentors may in turn encourage more female students to join teams and increase female student participation and confidence in team activities. There has been a wealth of literature on the importance of providing girls with female role models, teachers, and mentors in STEM related fields. Prior research on male and female students studying calculus found that all students (female and male) had higher levels of participation and asked more questions when the class was taught by a female professor (Stout, Dasgupta, Hunsinger, \& MacManus, 2011). Other research on students majoring in engineering has shown that having female role models may lead to higher levels of perseverance (Amelink \& Creamer, 2010). Even at the early childhood and early elementary school level, research by Sullivan and Bers (2018) demonstrates that when girls in grades K-2 had a female robotics instructor they did not exhibit gender differences with boys in performance on programming tasks. However, when they had a male instructor, boys in the study performed statistically significantly better than girls on advanced programming tasks (Sullivan \& Bers, 2018). Future work will continue to look at the impact of VEX mentor gender on female students' engagement, confidence, and enjoyment of robotics activities.

\section{IMPLICATIONS FOR SUPPORTING FEMALE VEXSTUDENTS}

The results from this study highlight many areas where female VEX students are excelling. Female VEX students are equally confident compared to male students in many competition areas including programming, writing, presenting, and more. Additionally, their mentors generally felt that female students required less help than male students when it came to interpersonal skills such as collaborating.

However, the findings collected in this study also opened up two areas where female students can be better supported on VEX teams: building their confidence and building their technical expertise (particularly with physical construction tasks). These two areas may be interrelated, as it is likely that once female students are able to gain more experience with construction tasks they will also be more confident in themselves. Future work should look at whether increasing girls' technical competence will lead to increased confidence on VEX tasks.

\section{Increasing female students' confidence}

Results from this study indicate that it may be beneficial for VEX mentors to develop strategies for building female students' confidence in their technical skills and abilities. Male students in this study were statistically significantly more confident than female students in their ability to put things together and their general technical ability $(p<.05)$. Meanwhile, female students were not more confident than male students in any area. This is aligned with research in other male-dominated STEM domains, namely mathematics, where males are generally more confident in their abilities than females. For example, past research on female adolescents has shown that they are typically much more 
negative in the way they self-assess their mathematics ability than male adolescents (Correll, 2001). It is also aligned with research on gender differences and self-efficacy in technological fields. SelfEfficacy (or one's expectancy of success) is an important part of how we make educational and occupational choices (Correll, 2004). Many studies have demonstrated that women's computer selfefficacy is lower than men's, which may be one reason why there are fewer women in these fields (Beyer, 2014; Cassidy \& Eachus, 2002; Colbeck, Cabrera, \& Terenzini, 2001; Salminen-Karlsson, 2009; Zarrett, Malanchuk, Davis-Kean, \& Eccles, 2006). It is possible that increasing girls' confidence is as important as increasing their competence or knowledge in engineering areas.

\section{Increasing female students' technical expertise}

One reason female students may be less confident in their technical and building skills is that female students may simply have less experience with building, tinkering, and constructing prior to joining a robotics competition team in middle or high school team. Many mentors commented that male students came in with an abundance of prior experience from their younger years, using materials like LEGOs. This supports prior research (e.g., Sullivan \& Bers, 2016) that suggests it is critical to begin introducing girls to engineering and robotics in early childhood. Research has shown that women often have less experience with tinkering during their childhoods compared to men (McIlwee \& Robinson, 1992). By providing female students with opportunities to build, play, and explore with construction and engineering toys as well as developmentally appropriate technologies throughout their early childhoods, it is possible that they will be more experienced and confident in these domains by the time they reach late elementary and middle school.

When it comes to mentoring female students on VEX teams who may not have had these early childhood experiences, it is important to offer them safe experiences where they are welcomed to play, tinker, and learn without fear of making mistakes. This could happen in several ways. For example, mentors could offer optional training workshops using different tools and materials that welcomes introductory students with no prior background. This could also help to attract more students, of any gender, who are nervous about joining a competition team because they lack the proper preparation. Other mentors may choose to run workshops or training sessions that are just for female students. This may be especially useful when run by a female mentor who can talk about the journey of being a female in STEM.

\section{LIMITATIONS}

Although this study had a large overall sample size, the majority of participants were mentors, not students. Therefore, the primary limitation of this study is the relatively small sample student size. The low student survey response rate may have been due to several factors including the process of obtaining consent from parents, limitations on being allowed to reach out to students directly, and more. The results of this study are further limited by the self-selected nature of this sample, which is common in recruiting for online survey-based research. While solicitations were sent to the mentors and parents of hundreds of potential participants, those who took the survey were self-motivated to participate and did not represent a random sample of the VEX population. It is possible that the demographic information, experiences, and opinions of students who did not complete this survey would have reflected different trends and results.

\section{FUTURE WORK}

Future work will continue to track the students and mentors who participated in the present research in order to gain valuable information about gender differences in retention and other longitudinal trends. New mentors and students will also be recruited to participate in order to calculate trends from a larger and more representative sample in order to address some of the limitations previously described. Additionally, future work will begin to look at whether there is a correlation be- 
tween experiences in early childhood and early elementary school and participation on VEX teams during middle and high school.

\section{CONCLUSION}

Men continue to outnumber women in fields like computer science and engineering (National Science Foundation, 2017). It is critical for researchers and educators to develop strategies to engage girls and young women in technology and engineering during their K-12 years so that they will be equipped with equal opportunities to pursue these fields in college and beyond. Robotics competitions are widespread and can be an effective way to get students involved with technology, coding, engineering, and design as early as elementary school. However, with male students outnumbering female students, these competitions are currently a just another missed opportunity to engage girls in STEM. Future work is needed to delve deeper into this area and ensure that robotics competitions are welcoming and supportive of people of all genders.

\section{REFERENCES}

Amelink, C. T., \& Creamer, E. G. (2010). Gender differences in elements of the undergraduate experience that influence satisfaction with the engineering major and the intent to pursue engineering as a career. Journal of Engineering Education, 99, 81-92. https://doi.org/10.1002/j.2168-9830.2010.tb01044.x

Bers, M. U. (2008). Blocks, robots and computers: Learning about technology in early childhood. New York, NY: Teacher's College Press.

Bers, M. U. (2018). Coding as a playground: Programming and computational thinking in the early childhood classroom. New York, NY: Routledge press.

Beyer, S. (2014). Why are women underrepresented in computer science? Gender differences in stereotypes, self-efficacy, values, and interests and predictors of future CS course-taking and grades. Computer Science Education, 24(2-3), 153-192. https://doi.org/10.1080/08993408.2014.963363

Cassidy, S., \& Eachus, P. (2002). Developing the computer user self-efficacy (CUSE) scale: Investigating the relationship between computer self-efficacy, gender and experience with computers. Journal of Educational Computing Research, 26, 133-153. https://doi.org/10.2190/JGJR-0KVL-HRF7-GCNV

Colbeck, C. L., Cabrera, A. F., \& Terenzini, P. T. (2001). Learning professional confidence: Linking teaching practices, students' self-perceptions, and gender. The Review of Higher Education, 24, 173-191. https://doi.org/10.1353/rhe.2000.0028

Corbett, C., \& Hill, C. (2015). Solving the equation: The variables for women's success in engineering and computing. Washington, DC: American Association of University Women. Retrieved from https:// files.eric.ed.gov/fulltext/ED580805.pdf

Correll, S. J. (2001). Gender and the career choice process: The role of biased self-assessments. American Journal of Sociology, 106(6), 1691-1730. https://doi.org/10.1086/321299

Correll, S. J. (2004). Constraints into preferences: Gender, status, and emerging career aspirations. American Sociological Review, 69, 93-113. https://doi.org/10.1177/000312240406900106

Doerschuk, P., Liu, J., \& Mann, J. (2007). Pilot summer camps in computing for middle school girls. ACM SIGCSE Bulletin, 39(3), 4-8. https://doi.org/10.1145/1269900.1268789

Fayer, S., Lacey, A., \& Watson, A. (2017). STEM occupations: Past, present, and future. Spotlight on Statistics. U.S. Bureau of Labor Statistics. Retrieved from https://stats.bls.gov/spotlight/2017/science-technologyengineering-and-mathematics-stem-occupations-past-present-and-future/pdf/science-technologyengineering-and-mathematics-stem-occupations-past-present-and-future.pdf

Fortier, M. S., Vallerand, R. J., Briere, N. M., \& Provencher, P. J. (1995). Competitive and recreational sport structures and gender: A test of their relationship with sport motivation. International Journal of Sport Psychology, 26, 24-24.

Girl Powered, (2018). Why girl powered? Retrieved from: https://www.girlpowered.com/why-girl-powered/ 
Hendricks, C. C., \& Alemdar, M., \& Ogletree, T. W. (2012). The impact of participation in VEX robotics competition on middle and high school students' interest in pursuing STEM studies and STEM-related careers. Paper presented at the ASEE Annual Conference, San Antonio, Texas. Retrieved from https://peer.asee.org/22069

Innovation First International. (2012). VEX competition overview. Retrieved from: http://www.vexrobotics.com/competition?ref=home

Kuhn, D., Nash, S. C., \& Brucken, L. (1978). Sex role concepts of two- and three-year-olds. Child Development, 49, 445-51. https://doi.org/10.2307/1128709

Madill, H., Campbell, R. G., Cullen, D. M., Armour, M. A., Einsiedel, A. A., Ciccocioppo, A. L., \& Coffin, W. L. (2007). Developing career commitment in STEM-related fields: Myth versus reality. In R. J. Burke, M. C. Mattis, \& E. Elgar (Eds.), Women and minorities in science, technology, engineering and mathematics: Upping the numbers (pp. 210-244). Northhampton, MA: Edward Elgar Publishing. https://doi.org/10.4337/9781847206879.00019

Mallinson, A. (2015). A mechanical engineering rite of passage at MIT. MIT News. Retrieved from http://news.mit.edu/2015/mechanical-engineering-rite-of-passage-1215

Markert, L. R. (1996). Gender related to success in science and technology. The Journal of Technology Studies, 22(2), 21-29. https://doi.org/10.21061/jots.v22i2.a.4

McIlwee, J. S., \& Robinson, J. G. (1992). Women in engineering: Gender, power, and workplace culture. New York, NY: SUNY Press.

McKown, C., \& Weinstein, R. S. (2003). The development and consequences of stereotype-consciousness in middle childhood. Child Development, 74, 498-515. https://doi.org/10.1111/1467-8624.7402012

Melchior A, Cutter T, \& Cohen, F. (2004) Evaluation of FIRST LEGO league. Center for Youth and Communities, Heller Graduate School, Brandeis University.

Metz, S. S. (2007). Attracting the engineering of 2020 today. In R. Burke and M. Mattis (Eds.), Women and minorities in science, technology, engineering and mathematics: Upping the numbers (pp. 184-209). Northampton, MA: Edward Elgar Publishing. https://doi.org/10.4337/9781847206879.00018

National Center for Science and Engineering Statistics. (2013). Women, minorities, and persons with disabilities in science and engineering: 2013. Special Report NSF 13-304. Arlington, VA. Retrieved from http://www.nsf.gov/statistics/wmpd/

National Science Board. (2014). Science and engineering indicators 2014. Arlington VA: National Science Foundation (NSB 14-01). Retrieved from https://www.nsf.gov/statistics/seind14/

National Science Foundation. (2017). Women, minorities, and persons with disabilities in science and engineering: 2017. Special Report NSF 17-310. Arlington, VA. Retrieved from www.nsf.gov/statistics/wmpd/

Passer, M. W. (1983). Fear of failure, fear of evaluation, perceived competence, and self-esteem in competitivetrait-anxious children. Journal of Sport Psychology, 5(2), 172-188. https://doi.org/10.1123/jsp.5.2.172

Petre, M., \& Price, B. (2004). Using robotics to motivate 'back door 'learning. Education and Information Technologies, 9(2), 147-158. https://doi.org/10.1023/B:EAIT.0000027927.78380.60

Rusk, N., Berg, R., \& Resnick, M. (2005). Rethinking robotics: Engaging girls in creative engineering. Proposal to the National Science Foundation, Cambridge. Retrieved from https://www.media.mit.edu/publications/rethinking-robotics-engaging-girls-in-creative-engineering-2/

Salminen-Karlsson, M. (2009). Women who learn computing like men: Different gender positions on basic computer courses in adult education. Journal of Vocational Education and Training, 61(2), 151-168. https://doi.org/10.1080/13636820902933254

Signorella, M. L., Bigler, R. S., \& Liben, L. S. (1993). Developmental differences in children's gender schemata about others: A meta-analytic review. Development Review. 13, 147-183.

https://doi.org/10.1006/drev.1993.1007

Spielhagen, F. R. (2008). Having it our way: Students speak out on single-sex classes. In F. R. Spielhagen (Ed.), Debating single-sex education: Separate and equal (pp. 32-46). Baltimore: Rowan \& Littlefield. 
Gender Differences in VEX Robotics Competition Student Experiences

Steele, C. M. (1997). A threat in the air: How stereotypes shape intellectual identity and performance. American Psychologist, 52, 613- 629. https://doi.org/10.1037/0003-066X.52.6.613

Stephenson, K. (2018). Over 30,000 students help to break the record for largest robot competition. Guinness book of world records. Retrieved from:

http://www.guinnessworldrecords.com/news/commercial/2018/5/over-30-000-students-help-to-breakthe-record-for-largest-robot-competition-525746

Stout, J. G., Dasgupta, N., Hunsinger, M., \& MacManus, M. A. (2011). STEMing the tide: Using in-group experts to inoculate women's self-concept in science, technology, engineering, and mathematics (STEM). Journal of Personality and Social Psychology, 100(2), 255-270. https://doi.org/10.1037/a0021385

Sullivan, A. (2016). Breaking the STEM Stereotype: Investigating the use of robotics to change young children's gender stereotypes about technology and engineering. (Doctoral Dissertation). Tufts University, Medford, MA. Retrieved from https:// sites.tufts.edu/devtech/files/2018/03/Sulllivan-Dissertation-2016-compressed.pdf

Sullivan, A., \& Bers, M. U. (2016). Girls, boys, and bots: Gender differences in young children's performance on robotics and programming tasks. Journal of Information Technology Education: Innovations in Practice, 15, 145165. https://doi.org/10.28945/3547

Sullivan, A. \& Bers, M. U. (2018). The impact of teacher gender on girls' performance on programming tasks in early elementary school. Journal of Information Technology Education: Innovations in Practice, 17, 153-162. https://doi.org/10.28945/4082

Witherspoon, E. B., Schunn, C. D., Higashi, R. M., \& Baehr, E. C. (2016). Gender, interest, and prior experience shape opportunities to learn programming in robotics competitions. International journal of STEM Education, 3(1), 18. https://doi.org/10.1186/s40594-016-0052-1

Zarrett, N. R., Malanchuk, O., Davis-Kean, P. E., \& Eccles, J. (2006). Examining the gender gap in IT by race: Young adults' decisions to pursue an IT career. In J. M. Cohoon \& W. Aspray (Eds.), Women and information technology (pp. 55-88). Cambridge, MA: MIT Press. https://doi.org/10.7551/mitpress/9780262033459.003.0002

Zweben, S., \& Bizrot, B. (2015). 2014 Taulbee survey. Retrieved from the Computing Research Association website, https://cra.org/wp-content/uploads/2015/06/2014-Taulbee-Survey.pdf

\section{BIOGRAPHIES}

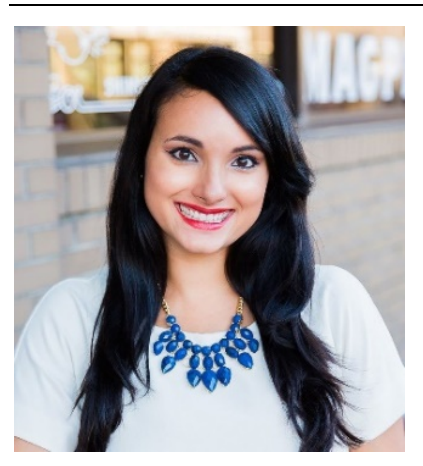

Dr. Amanda Sullivan is the Associate Director of the Early Childhood Technology (ECT) Graduate Certificate Program at Tufts and a researcher with the DevTech Research Group. She has a Master's and Ph.D. in Child Development from the Eliot-Pearson Dept. of Child Study \& Human Development at Tufts University where she specialized in educational technology for young children. Amanda's research focuses on exploring gender differences in STEM fields and developing strategies for engaging girls and women in technology and engineering. Her upcoming book: Breaking the STEM Stereotype: How to Reach Girls Beginning in Early Childhood will be released next year.

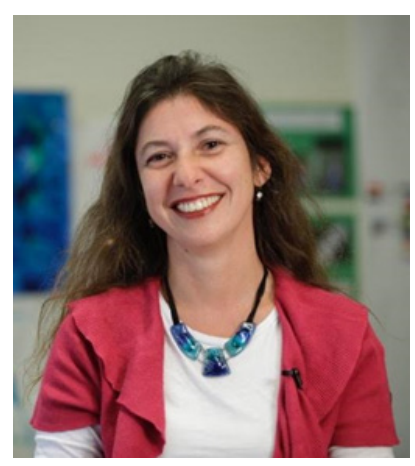

Professor Marina Umaschi Bers is Co-Founder and Chief Scientist at KinderLab Robotics; Professor and Chair, Eliot-Pearson Department of Child Study and Human Development; Adjunct Professor, Computer Science Department; Director, DevTech Research Group, Tufts University; Director, Early Childhood Technology (ECT) Graduate Certificate Program, Tufts University; and Author of Coding as Playground: Computational Thinking in the Early Childhood Classroom (2018), Designing Digital Experiences for Positive Youth Development: From Playpen to Playground (2012), and Blocks to Robots: Learning with Technology in the Early Childhood Classroom (2007) 